\title{
The Importance and Benefits of Relationship Marketing Concept
}

\author{
Yakup Durmaz, Habip Güvenç, and Selman Kaymaz
}

\begin{abstract}
The purpose of this study is to explain the concept and benefits of relationship marketing. The relationship marketing term that includes establishing short, medium and long-term ties-relationships with the customers, continuing and developing these relationships was first introduced by Berry in 1983. The concept of relationship marketing is a vital and important step in ensuring profit satisfaction and customer satisfaction in recent years, as well as achieving competitive advantage in the global market. Almost all of the big corporate enterprises in our country have turned to relationship marketing models and practices on issues such as ensuring customer satisfaction, determining customer expectations, product development, strengthening customer loyalty, product development and product differentiation.
\end{abstract}

Index Terms - Relationship marketing, Traditional marketing, Importance of relationship marketing, Benefits of relationship marketing

\section{INTRODUCTION}

Changes in the needs, wishes, expectations and demands of customers and buyers as global and local competition conditions become tough have increased pressures and innovations on businesses. It has been inevitable for businesses and big brands to take different initiatives in order to gain competitive advantage and adapt to changes related to customers. In this context, businesses aimed to preserve their existing customers and turn them into more loyal customers for businesses rather than acquiring new customers in marketing practices. Accordingly, it has created the importance and awareness of relationship marketing, which is a new model in terms of marketing [9].

In this study, the concept of relationship marketing, its definition, its differences with classical marketing, its benefits, strategies, stages and negative judgments on relationship marketing are discussed.

\section{Definition And Meaning Of Relationship MARKETING}

\section{A. Definition of Relational Marketing}

With the effect of the differences in the needs of customers and businesses, the science and concept of marketing has shown a continuous development and change in accordance with the requirements of the age. With these changes and developments in the science of marketing in the global world, it has been determined that since the 1970s, scientists have been concerned with issues such as

Published on August 27, 2020.

Yakup Durmaz, Hasan Kalyoncu University, Turkey. (corresponding e-mail: yakup.durmaz ${ }^{@}$ hku.edu.tr)

Habip Güvenç, Hasan Kalyoncu University, Turkey.

(e-mail: bedirhanguvenc@yahoo.co.uk)

Selman Kaymaz, Hasan Kalyoncu University, Turkey. establishing, building and managing relations in markets [4]. This interest and relevance has led to new occurrences and phenomena in marketing steps and strategies through relationships with the customer in order to establish connections.

Relational marketing as a concept was first mentioned by Berry in 1983. Berry mentioned to the concept of relationship marketing as creating, maintaining and improving the relationships of customers addressed in many different service organizations [1]. Relational marketing has also been described as a strategy that focuses on developing and maintaining good relationships with existing customers, rather than finding new customers, as opposed to traditional marketing [6]. According to the scientist Gummesson, when he mentioned the concept of relational marketing, he mentioned his aims and includes the following activities [8]:

- Developing a service culture where the customer is the most important one;

- Making promises to the customer and fulfilling the promises in turn;

- Collecting customer data and using this information in the right place;

- Implementation of the interaction and change process required for marketing activities;

- Focusing on the customer in the medium and long term, touching the benefit;

- Spreading of marketing activities to all staff with the awareness of quality is whole.

\section{B. The Importance of Relationship Marketing}

Scientists have stated below the reasons why relational marketing is at a valuable point [3]:

- Upward change of total quality standards and criteria;

- The way customers buy products constantly changes;

- Increasing competition in the global world and difficult market conditions;

- The rise in breaks in global markets;

- Increasing direct and indirect impact of changing technology;

- Only quality-oriented product mission is not sufficient;

- Changing customer tensions and intergenerational differences;

- Traditional / Classic marketing's depreciation.

Relationship marketing tries to maintain more fresh and useful information and permanent relationships by staying in touch with the customers who are important in the globalizing market.

\section{Differences between Traditional Marketing and Relationship Marketing}

Traditional marketing is profit, sales and productoriented; added customer satisfaction to these concepts from the customer-centered relationship marketing point. Table 1 shows the main differences between relationship marketing 
and traditional marketing.

TABLE I: DIFFERENCES BETWEEN TRADITIONAL MARKETING AND RELATIONSHIP MARKETING

\begin{tabular}{ll} 
Traditional Marketing & Relationship Marketing \\
- Focus on single sales & - Customer retention \\
- Intermittent customer relationship & - Continuous customer \\
- Focus on product features & relationship \\
- Short-term view & - Focus on customer value \\
- Little emphasis on customer service & - Long-term view \\
- Limited commitment to customer & - Emphasis on customer service \\
expectations & - High commitment to meet \\
- Quality concerns only production & customer expectations \\
personnel. & -Quality concerns all staff \\
\hline
\end{tabular}

\section{BenEFITS AND StAgEs Of RELATIONShip MARKETING}

\section{A. Benefits of Relationship Marketing}

Relationship marketing generally has benefits such as increasing the level of customer satisfaction to higher levels easily, reaching profitable customers easily, and providing a competitive advantage with word-of-mouth advertising on the business and customer side [7].

On the business side:

- Achieving Competitive Advantage;

- Providing Easier Customer Satisfaction;

- Mouth to Mouth Marketing;

- Reaching Profitable Customers.

On the Customer Side:

- Special Care and Treatment and Trust-Accuracy (Less Risk Perception);

- Social, Sincere and Friendly Benefits.

It can be seen above that relational marketing has benefits.

\section{B. Stages of Relationship Marketing}

Relationship marketing needs to go through four steps for existence and implementation. These are as follows [5]:

- Separating and Differentiating Customers Identified by Selecting and Identifying Customers.

- Interacting and Contacting These Customers.

- Then Expanding the Product or Service and Presenting it to All Customers.

\section{Strategic Step Relationship Marketing}

In all areas, relationship marketing affects the quality of the product and service and communication with the customer from an important point. Relationship marketing strategies consist of:

- Internal Marketing (ensuring employee satisfaction and motivation).

- Making the Relationship and Product Compatible (Customer-Personalized).

- Relational-Personal Price Formation.

- Product Quality is at the Top Level and Service Increase.

\section{CONCLUSION}

Since the survival of businesses in the globalizing and even shrinking world market is difficult compared to the past, businesses should be able to master all the characteristics of the customer and their knowledge, habits and behaviors. Any ties that can reach the customers, even networks in the future, will propel costumers towards the company as loyal customers. A customer-oriented sales strategy should be formed in order for the sales share in the market to be more permanent, as the conditions of customer satisfaction must be met. This is possible with relationship marketing.

In order to create a long-lasting link that understands the customer, businesses must follow the customer's habits and meet their demands as soon as possible. Thereby, customer becomes loyal to the business. In this respect, customer relations, call centers, employees, customer demands, problem solution points and various product categories will lead to an even more advanced customer-business relationship.

\section{REFERENCES}

[1] Berry, L. L. (2002). Relationship Marketing Of ServicesPerspectives From 1983 And 2000. Journal Of Relationship Marketing. Volume 1, Number 1. 59-77. Erişim Tarihi: 18.10.2012.

[2] Gummesson,E.(2008). Total Relationship Marketing: Marketing Management, Relationship Strategy, Crm, And A New Dominant Logic For The Value-Creating Network Economy. (3.Bask1). Oxford: Elsevier Ltd. Erişim Tarihi: 05.11.2012.

[3] Kandampully, J. Ve Duddy, R. (1999). Relationship Marketing: A Concept Beyond The Primary Relationship.Marketing Intelligence \& Planning, Vol. 17 Iss: 7 Pp. 315- 323. Erișim Tarihi: 05.11.2012, Emerald Veritabanı.

[4] Nakıboğlu, M.A.B. (2008). Hizmet İşletmelerindeki İlişkisel Pazarlama Uygulamalarının Müșteri Bağlılığı Üzerindeki Etkileri. Doktora Tezi. Adana: T.C. Çukurova Üniversitesi. Sosyal Bilimler Enstitüsü. Erişim Tarihi: 15.10.2012.

[5] Odabaşı, Y. (2000). Satışta Ve Pazarlamada Müşteri İlişkileri Yönetimi (1.Bask1). İstanbul:Sistem Yayıncılık.

[6] Öztürk, S.A. (1998). Hizmet Pazarlaması. Eskişehir: Anadolu Üniversitesi Yayınları No: 1028, İşletme Fakültesi Yayınları No:3.

[7] Selvi, M.S. (2007). İlişkisel Pazarlama Stratejiler Ve Teknikler (1. Baskı). Ankara: Detay Yayıncılık.

[8] Şendur, F. (2009). İlişkisel Pazarlama Çerçevesinde Müşteri Değeri Yaratmanın Önemi: Bankacılık Sektöründe Bir Araștırma. Yüksek Lisans Tezi. Balıkesir: T.C. Balıkesir Üniversitesi. Sosyal Bilimler Enstitüsü. Erişim Tarihi: 15.10.2012.

[9] Yağan, E. (2010). İlișki Pazarlaması Uygulamalarının Müșteri Sadakati Yaratmadaki Rolüyüksek Lisans Tezi. Ankara: T.C. Ankara Üniversitesi. Sosyal Bilimler Enstitüsü. Erişim Tarihi: 25.10.2012, Http://Tez2.Yok.Gov.Tr/.

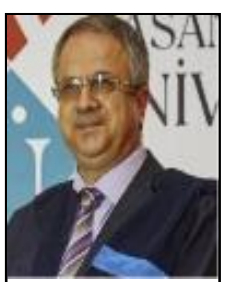

Assoc. Prof. Dr. Yakup DURMAZ:

License; Anadolu University

Department of Economics

Master: Kahraman Maraş Sutcu

Imam University, Business Administration

Department

PhD: İnonu University Marketing Department.

Habib Güvenç: Hasan Kalyoncu University PhD Student

Selman Kaymaz: Hasan Kalyoncu University Master Student 